\title{
'Ye shall disturbe noe mans right': oath-taking and oath-breaking in late medieval and early modern Bristol
}

\author{
JAMES LEE \\ School of History, University of the West of England, Bristol, St Matthias Campus, \\ Bristol BS16 2JP
}

\begin{abstract}
Oaths of office are generally well preserved for many English towns and cities and they can tell us a great deal about the theoretical and (perhaps to a lesser extent) practical duties of office-holders. In the light of recent scholarly interest in oaths in the context of investiture ceremonies, this article examines the rhetoric of oath texts to highlight some aspects of the political cultures of urban office-holding elites and their attempts to maintain stability.
\end{abstract}

Every year on Michaelmas day in late medieval Bristol the city's civic officers gathered at the Guildhall to witness the incoming mayor of Bristol take his oath of office for the following year from the outgoing mayor. ${ }^{1}$ As part of the ceremony the outgoing mayor made a departing speech before formally introducing the new mayor. First, he offered to amend any offence he may have caused to any person during his mayoralty. Secondly, he thanked his 'Maisters and ffrendes'; 'for in you hath bene trewe obedience to kepe the king our alther liege lorde is lawes, and my commaundment in his name, at all tymes'. ${ }^{2}$ In raising these issues the mayor was reflecting on the two fundamental responsibilities of his office which had been central to the oath he had sworn the previous year; his accountability to the community and his protection of law and order in the city. Both these concerns were crucial to the maintenance of peace and stability in late medieval and early modern Bristol.

Michaelmas and the days immediately following were extremely significant not only for the civic authorities in Bristol, but also for the local community as a whole. After the new mayor had taken his oath a number of other Bristol civic officials (including the sheriff, bailiffs and town clerk), and the city's chantry priests and master craftsmen, took their

${ }^{1}$ Robert Ricart, The Maire of Bristowe Is Kalendar, ed. L. Toulmin Smith, Camden Society, n.s. V (1872-3) (hereafter Ricart's Kalendar), 69-70.

2 Ibid., 71. 
oaths over the next four days. ${ }^{3}$ By the end of these four days of intense activity, therefore, the personnel of the Bristol civic office-holding elite had been reconstituted and confirmed for the following mayoral year. ${ }^{4}$

The Bristol mayor's inauguration was commemorated by a display of civic authority and splendour which was extravagantly illustrated and entered into the city's most famous history, The Maire of Bristowe Is Kalendar, begun by Robert Ricart in $1479 .{ }^{5}$ Urban ceremonies and rituals such as this have excited a great deal of scholarly interest. A number of historians have interpreted such events as reflections of the civic order and as therefore helping to bind urban communities together. By contrast, other scholars have suggested that far from solidifying community ties, such occasions were symptomatic of, and perhaps even encouraged, divisiveness. ${ }^{6}$ Historians have, however, generally been less concerned to study the significance of the language of the oaths which were central to these ceremonies. ${ }^{7}$ Indeed, more than the ceremonial surrounding oath-takings, it is clear that it was the text of the oath itself which was regarded by contemporaries as legitimating power to the office-holder. ${ }^{8}$ By analysing the political rhetoric of oaths of office this article will argue that while such oaths ostensibly laid claim to upholding civic liberties, this device also concealed significant divisions within the urban community; divisions which urban elites were keen to overcome in order to maintain peace and stability in their cities.

By the time Ricart began his Kalendar in the late fifteenth century oaths had established themselves as an essential part of the legal and cultural fabric of English urban society. ${ }^{9}$ As urban administrations became more sophisticated the number of oaths of office increased also. ${ }^{10}$ Indeed, such was their importance that a number of towns and cities organized their

${ }^{3}$ Ibid., 75-8.

${ }^{4}$ The city's common councillors, aldermen and recorder were chosen on an ad hoc basis as and when vacancies arose, James Lee, 'Political communication in early Tudor England: the Bristol elite, the urban community and the Crown, c. 1471-c.1553' (unpublished University of the West of England Ph.D. thesis, 2006), ch. 6.

${ }^{5}$ For similar celebrations in London see Michael Berlin, 'Civic ceremony in early modern London', Urban History Yearbook (1986), 15-27. See also William Yonger, The Nurses Bosome. A Sermon within the Greene-Yard in Norwich. On the Guild-day when their Maior Takes his Oath... June 18. 1616 (London, 1617).

6 The debate is conveniently summarized in Ben McRee, 'Peacemaking and its limits in late medieval Norwich', English Historical Review, 111 (1994), 831-66.

7 The latest work on the culture of oaths is not urban specific, John Spurr, 'A profane history of early modern oaths', Transactions of the Royal Historical Society, 6th ser. 11 (2000), 37-63.

8 The York mayor-elect, Thomas Wrangwish, for example, refused to be accompanied by the mayor's swordbearer and serjeants bearing the sword and mace of office, because he was unsworn, The York House Books, 1461-1490, ed. L.C. Attreed, 2 vols. (Gloucester, 1991), vol. I, 301-2, vol. II, 426.

9 Oaths as legal devices in this period are discussed in J.G. Bellamy, Crime and Public Order in England in the Later Middle Ages (London, 1973).

10 The Book of Oaths (London, 1649), for example, 'lists over 400 pages of oaths taken by government officials ranging from privy councillors to midwives and scavengers', David Martin Jones, Conscience and Allegiances in Seventeenth-Century England. The Political Significance of Oaths and Engagements (New York, 1999), 32. 
early records around the oaths of their civic officials. ${ }^{11}$ The Little Red Book of Bristol contains the texts of 28 separate oaths of office from the fourteenth and fifteenth centuries, including the oaths of the city's chantry priests and craft and civic officials. ${ }^{12}$ As leaders of their respective communities, the primary aim of the civic, company and parish elite officers was to ensure peace and stability in the monarch's city. Their oaths reveal some of the ways, perhaps the most important ways, in which they sought to do this.

\section{Oath-taking and urban stability}

Ignoring the specific charges relevant to individual officers' duties, there are a number of similarities between many of the Bristol oaths of office from this period. Civic oaths often began by charging the supplicant to swear allegiance to the monarch. The mayor expressed this with a special sensitivity describing how 'trewly with all my power I shall save and kepe this his Toune of Bristow, to hym and to his heires and to his successours'; a reflection of the fact that he acted as the king's lieutenant in the city. ${ }^{13}$ The mayor's oath also emphasized his duty to maintain order in the city; 'I shall kepe and meyntene the peas... I shall reprove and chastice the misrewlers and mysdoers. ${ }^{14}$ However, in common with many other Bristol oaths of office, the mayor qualified this by vowing that he 'shall trewly, and with right, trete the people of my bailly, and do every man right, as wel to the poer as to the riche... And nouther for ghifte, nor for love, affeccion, promesse, nor for hate, I shall do no man wronge, nor destourbe no mannes right. ${ }^{\prime 15}$ The sheriff's oath echoed the mayor's with the simple instruction, 'ye shall disturbe noe mans right'. ${ }^{16}$ Similar concern for the maintenance of peace and stability was also reflected in Bristol's occupational organizations. After the election of the Merchant Taylors' company's new elite officials, the new wardens made their oaths

11 See, for example, The Oath Book or Red Parchment Book of Colchester, ed. W.G. Benham (Colchester, 1907).

12 The Little Red Book of Bristol, ed. F.B. Bickley, 2 vols. (Bristol, 1900), vol. I, 45-56. Ricart's Kalendar gives the texts of five oaths of office and mentions a further eight without detailing the full texts, Ricart's Kalendar, 72-7, 87-90. Bristol Record Office (BRO) 04371, Book of Oaths, dated 1813, lists some 43 individual civic oaths of office.

13 Ricart's Kalendar, 72.

$14 \mathrm{Ibid}$. The Norwich mayor similarly swore to 'susteyn executen and mayntene... [th]e pes and tranquillite' in the city, The Records of the City of Norwich, ed. W. Hudson and J.C. Tingey, 2 vols. (Norwich, 1906), vol. I, 123.

15 Ricart's Kalendar, 72, 89. In this respect, the mayor's oath mirrored that of the judges of the central law courts, see Sir John Baker, The Oxford History of the Laws of England, vol. VI: 1483-1558 (Oxford, 2003), 227, 230. Remembering his charge to respect the needs of the poor as well as the rich, the mayor of York, William Todde, for example, wrote to Sir Hugh Hastings in April 1487 explaining that he would 'doo no prejudice unto the porest of the commons here standing as I stand, for an hundreth powndes, remembering the othe which I have takyn and in especiall in this my begynnyng in thoffice of mairaltye', York House Books, ed. Attreed, vol. II, 545.

16 Ricart's Kalendar, 89. 
'to govern well and lawfully the said fraternity and the craft and all their liberties and good ordinances'. ${ }^{17}$ The oaths of the leaders of the civic and company communities thus disclose an apparent awareness that the extent of their public power and authority as elite officers did not sanction them with the right to meddle unreasonably with the private liberties of individual members of their community. The liberties of individuals were also ostensibly safeguarded by the sworn obligation placed on many civic and company elites to rule impartially. The wardens of the Bristol Merchant Taylors' company, for example, were charged to carry out their duties 'notwithstondyng love ne drede of frende, ne felawe nor of non other man wher of the commune pr[o]fite be not abregged and yrto ye plighte yor trewth'. ${ }^{18}$ Similarly, the masters of the Bristol Soapmakers' Company swore to deal 'equally and uprightle' with every person of the company. ${ }^{19}$

Elite oaths of office thus compelled office-holders to reflect on the obligations of their office. Indeed, the demands of an oath and the responsibilities it entailed could sometimes persuade an individual not to bind himself to it. In late fifteenth-century Coventry, for example, Thomas Kebell was handed a copy of the recorder's oath of office so that he might gauge his suitability for the role. ${ }^{20}$ Kebell subsequently declined the post, believing himself incapable of guaranteeing his presence at the Coventry assizes and sessions of the peace as demanded by the recorder's oath. Oaths of office therefore represented a set of standards and values which it was expected the subscriber would uphold and adhere to. Furthermore, it was considered crucial that the scope and meaning of oaths was both plainly conveyed and clearly understood by all interested parties. All those admitted to the Bristol Merchant Taylors' company, for example, were expected to gather in the fraternity's chapel in St Ewen's Church, Bristol (or in some other 'honest' place designated by the company's master), every quarter day 'to hear the ordinances read before all the company, that every of them may the better know the ordinances and the meaning of the required oath'. ${ }^{21}$

However, by its very nature, oath-taking was a divisive act. Subscription to an oath of office at civic or company level linked the new official to fellow office-holders past and present. At civic, company and parish level,

17 F.F. Fox, Some Account of the Ancient Fraternity of the Merchant Taylors of Bristol with transcripts of ordinances and other documents (Bristol, 1880), 11-12. The master's and warden's oaths of the Coventry Drapers' Company echoed the Bristol civic elite's emphasis on equity, requiring them to be just in their office and to wrong neither the fellowship nor its members, Coventry Archives PA 99/1 fols.10v, 10r.

18 Fox, Merchant Taylors of Bristol, 29-30.

19 Proceedings, Minutes and Enrolments of the Company of Soapmakers, 1562-1642, ed. H.E. Matthews (Bristol Record Society (BRS), 1940), 59, dated January 1603.

20 The Coventry Leet Books, ed. M.D. Harris, 2 vols. (Early English Text Society, London, 190713), vol. I, 524-5.

${ }^{21}$ Fox, Merchant Taylors of Bristol, 7. 
oath-taking for elite offices acted as a gateway to the social, political and economic elite ranks of each part of the urban community. By the same token, however, it could serve to distance the individual from other sectors of the community. This process of demarcation was most explicit at civic level as select burgesses took the oath of common councillors. As well as charging the oath-taker with providing 'trewe and hole counsell' to the mayor, the fifteenth-century oath of the Bristol common councillor required him to 'stonde holiche with the Mair, Sheriffe, Bailiffs and all the worthy men and all the Comonaltee of the towne of Bristowe in all maner matiers, causes and nedes'. ${ }^{22}$ The councillors' oath thus served to bind the councillor alongside other members of the elite. By the end of the sixteenth century, the distinction between the Bristol councillors and the rest of the community was emphasized at every meeting of the common council after it was ordained that councillors would listen to their oath before each assembly. ${ }^{23}$ As David Harris Sacks has remarked, the Bristol common councillor's oath 'gave relations among the councillors a special intimacy which reinforced the sense of common purpose the oath was intended to instil'. ${ }^{24}$

Entry to the citizenry similarly marked a crucial point at which a person's political, social and economic status and identification was transformed. The requirement to take an oath was a form of insurance on behalf of the co-opting group. The group's elite used the oath as a means of insuring the good behaviour of its new member, as an agreement to abide by this new group's rules and regulations, and as a touchstone with which to gauge a person's suitability for membership. In this way all Bristol apprentices were required to demonstrate their competence as craftsmen before taking freeman's oaths before the mayor at the Tolsey court (an event which likewise conferred on the individual full membership of their craft). Furthermore, the apprentice's master had to be present as the apprentice made his oath to attest to the apprentice's good character. ${ }^{25}$ In this way, the oath gained its legitimacy from the authority of the craft and civic elites.

Oath-taking, in Bristol's case, did not therefore bind the individual to the entire community. ${ }^{26}$ Indeed, oaths and oath-taking, it could be more convincingly argued, encouraged separate community identities by binding the individual to elite minorities within a broader community of

${ }^{22}$ Little Red Book, ed. Bickley, vol. I, 1.

23 BRO B39, 26.

24 D.H. Sacks, 'Trade, society and politics in Bristol, 1500-1640' (unpublished Harvard University Ph.D. thesis, 1977), 101.

${ }^{25}$ Little Red Book, ed. Bickley, vol. I, 37-8, Calendar of the Bristol Apprentice Book, Part I, 1532-42, ed. D. Hollis (BRS, 14, 1949), 7.

26 Although agreeing on the pivotal importance of the oath of office, for David Shaw the Wells master's and burgess's oath bound men irrevocably to the broader urban community. Nevertheless, as Shaw demonstrates, by giving himself over 'to the Master and to all the burgesses', the supplicant thereby became a member of the town's elite, The Creation of a Community: The City of Wells in the Middle Ages (Oxford, 1993), 198. 
associated members. This process occurred at a variety of levels within the urban societal structure and was reinforced by the elite's conception of themselves as a private or secret society. At parish level, the clerk of All Saints' church, Bristol, swore 'to bear no tales between the vicar and his brethren, nor between him and his parishioners, nor between neighbour and neighbour, whereby any occasion of strife or debate should grow in time to come' ${ }^{27}$ The text of the clerk's oath acknowledged the fact that his now privileged position as a member of the parish administration also placed him in a vulnerable position in terms of his relationship with the wider body of parishioners. His oath bound him, therefore, to ensure the maintenance of good order in the parish by remaining loyal to the parish hierarchy, including the clergy, the churchwarden, the masters of the parish and the vestry. Similarly, at civic level, common councillors in fifteenth-century Bristol were reminded to keep the council's deliberations secret; 'all maner matiers the whiche oght to be kept counsell the schal kepe it counsell'. ${ }^{28}$ The concept of confidentiality or keeping secret the deliberations of the elite was an integral technique which helped to reinforce the elites' self-perpetuation. ${ }^{29}$ As members of the elite progressed through the extended cursus honorum of parish, company and civic offices, at each stage they swore to keep secret the deliberations they were privy to. This process helped to create and maintain a two-tiered level of political engagement in cities such as Bristol; a politics of inclusion and exclusion. ${ }^{30}$ In cities such as Bristol, where elite civic offices were exclusively the preserve of the wealthiest inhabitants, this political stratification could only have been exacerbated by further social and economic polarization. ${ }^{31}$

The maintenance of such an overtly hierarchical and potentially divisive political structure anticipated the prospect of disorder. Thus, the structure employed by urban authorities such as Bristol necessitated the use of devices such as oaths to help to ensure the maintenance of peace and stability in the city. The oaths of many of the city's civic elite office-holders shared the mayor's and sheriff's concern with the maintenance of good order in the

27 The oath dates from the late fifteenth century, The Pre-Reformation Records of All Saints: Bristol: Part 1, ed. Clive Burgess (BRS, 46, 1995), 2.

${ }^{28}$ Little Red Book, ed. Bickley, vol. I, 1. For similar stipulations in London see C.M. Barron, London in the Later Middle Ages: Government and People, 1200-1500 (Oxford, 2004), 132.

29 The need to keep secret common council deliberations was still impressed upon participants in York in the early eighteenth century, a practice reified by drinking wine from a communal black bowl, K.J. Allison and P.M. Tillott, 'York in the 18th century', in P.M. Tillott (ed.), A History of the County of Yorkshire: The City of York (Victoria County History (VCH), 1961), 239.

${ }^{30}$ For similar emphasis in other towns, see, for example, the Register of the Freemen of the City of York from the City Records, ed. F. Collins, 2 vols. (Surtees Society, 1897-1900), vol. I, xiv, where burgesses swore to keep 'the counseyle and privatez', and the oath of the Norwich common councillors; 'yat is seyd in common counsel and owght for to be kept counsell yt xal it counsell kepe and non yer of discoure', Records of the City of Norwich, ed. Hudson and Tingey, vol. I, 122.

${ }^{31}$ Lee, 'Political communication', chs. 5, 6 and 7. 
city. The recorder, for example, the city's principal legal adviser and 'good lord' at court, swore in his oath to give 'the best councell I can, without any partyalty, love, favour or hate'. Importantly, he also promised not to give counsel to anyone acting against the interests of the city, as well as 'any person of Common Counsell ... against any other of the same counssell' ${ }^{32}$

The system by which the oaths of elite civic office-holders were ratified highlighted the distinctiveness of the city's elite from the rest of the urban community and further enhanced the legitimacy of the civic elite. By the terms of Bristol's 1499 charter from the Crown, for example, the city's recorder took his oath before the mayor, the city's five aldermen took their oaths before the mayor and recorder, and the chamberlain gave his oath before the mayor, recorder and aldermen. ${ }^{33}$ Similarly, at company level, the city's Merchant Venturers met yearly within 14 days of Michaelmas to elect their own officials. ${ }^{34}$ The master of the Merchant Taylors' company was chosen by the outgoing master. 'In the middle of the dinner [the old master] shall put a garland upon the head of the new master, the which new master at the same day shall choose by the assent of his brothers there being four wardens, who at their election shall make their oaths to govern well and lawfully the said fraternity and the craft and all their liberties and good ordinances. ${ }^{35}$ The self-perpetuating legitimation of authority derived from oath-taking contributed to the use of elite oaths of office as a filtering mechanism which could be employed by groups wishing to restrict access to, and maintain standards within, their smaller, elite community.

Just as elite authorities in cities made use of oaths of office as a means of highlighting their power within the local community, the Bristol civic authorities were also able to exploit the symbolic value of their oath-taking to define their independent authority from external sources of political power. Prior to the city's 1373 charter of incorporation, the Bristol mayor took his oath of office before the constable of Bristol Castle; an external source of political power situated just outside the late medieval city. ${ }^{36}$

32 Ricart's Kalendar, 87. See also James Lee, 'Urban recorders and the Crown in late medieval England', in Linda Clark (ed.), The Fifteenth Century, vol. III: Authority and Subversion (Woodbridge, 2003), 173-4. As well as providing good counsel and advice to the ruling executive, recorders were also asked to be 'beneficial', 'faithful' and 'true' to the other town officers. The Wells' councillors and masters oaths of office similarly enjoined the swearer to act 'evenlye and indifferentlye', Shaw, Creation of a Community, 190-1.

33 Bristol Charters 1378-1499, ed. H.A. Cronne (BRS, 11, 1945), 169-70, 176. The sheriffs gave their oaths separately before the mayor only in the Guildhall.

34 Records relating to the Society of Merchant Venturers of the City of Bristol in the Seventeenth Century, ed. Patrick McGrath (BRS, 17, 1952), xi.

35 Ordinance dated 1401; Fox, Merchant Taylors of Bristol, 11-12.

${ }^{36}$ Similarly, the London mayor's oath-taking procession to Westminster to take his oath of office before the king, or in his absence, before the barons of the exchequer, was, according to Professor Caroline Barron, intended 'to remind the rulers of the City of London that they exercise authority in the City in the name of the monarch, who may suspend the liberties of the City if the rulers fail to hold London securely and peaceably for the Crown', 'The government of London and its relations with the Crown 1400-1450' (unpublished University of London Ph.D. thesis, 1970), 15. 
The city's 1373 charter revised this process by allowing the mayor to take his oath before the commonalty in the city's Guildhall. Only after his authority had been ratified by his peers, the Bristol civic elite, was the mayor presented to the constable of the castle and 'accepted by the same as heretofore was accustomed to be done' ${ }^{\prime}{ }^{37}$ In this way, the Bristol authorities were able to assert their independent political control both before the local community and external sources of power. ${ }^{38}$

In order to give their oaths credibility, and thus for other townspeople to respect the authority that oaths invested them with, officials were prudent not only to revere the terms of their own oaths but also to convey that veneration to the wider community. In 1469, for example, the London mayor and aldermen defended a request from a plaintiff for a writ of certiorari from the chancellor by insisting that the plaintiff's case had been treated fairly locally. They claimed that the plaintiff, Peter Pekham, had used opprobrious words against one of the city's aldermen in contempt of the oath of obedience he had taken when he became a freeman. ${ }^{39}$ Such cases also demonstrate that there could be little reprieve for those contravening the terms of their oaths. No member of the Bristol Merchant Taylors' company, for example, was permitted to be lawfully absent from the quarterly assemblies in which the company's ordinances were read aloud without reasonable cause upon 'peril of his oath if that he be in town and may come thereto' ${ }^{40}$

By combining both secular and sacred elements (by swearing to carry out one's duty to the community and thus, by implication, one's duty to God), oaths established, as Robert Tittler has argued, a spiritual reverence as well as a legal obligation to fulfil their terms ${ }^{41}$ Thus, the Bristol recorder took his oath in the late sixteenth century by swearing on the Bible and by asking for divine assistance; 'so helpe me God and the holly contents of

37 Bristol Charters, 1155-1373, ed. N. Dermot Harding (BRS, 1, 1930), 122-3; Ricart's Kalendar, 69. Andrew Brown's reading of the mayoral oath-taking at Salisbury (where the mayor took an oath before the bishop's bailiff) as an assertion of the power and status of the mayoralty could equally be interpreted as an assertion of the bishop's authority. By the same token, the incoming mayor's refusal in 1473 to undertake this ceremony was clearly an assertion of the mayor's authority, Andrew Brown, Popular Piety in Late Medieval England: The Diocese of Salisbury 1250-1550 (Oxford, 1995), 172.

38 Sheriffs' oaths of office in cities often highlighted the independence of cities from external jurisdictions by emphasizing the fact that urban sheriffs would not have to take any oaths outside the city, or before any other persons than the city's elite civic office-holders. See, for example, The Charters of the Borough of Southampton, vol. I: 1199-1480, ed. H.W. Gidden (Southampton Record Society, 1909), 74-5. Bristol's civic oaths were not, however, wholly independent of external influence. Indeed, amendments to oaths were made to reflect changes in national politics. During Henry VIII's reign the Bristol mayor's oath of office received an additional clause reminiscent of central government rhetoric for 'extynguisshing the auctoryte of the Bisshop of Rome'. Under Philip and Mary this clause was removed, Ricart's Kalendar, 72.

39 Calendar of letter-books of the city of London, ed. R.R. Sharpe, 11 vols. (London, 1899-1912), Letter Book L, 83-91.

40 Fox, Merchant Taylors of Bristol, 7.

41 Robert Tittler, The Reformation and the Towns in England (Oxford, 1998), 202. 
this booke'. ${ }^{42}$ The city's chantry priests also took their oaths, 'that is to seie, every of them to ley his lyfte hand on the boke [the Bible], and his righte hande on his brests, making his othe per sancta evangelica and per verba sacerdotis'. ${ }^{43}$ Whether, as Tittler suggests, oaths therefore cemented the loyalty and identity of the individual to the larger community, however, remains questionable. There is a danger here of assuming that theory corresponded with reality; that the ambitions and aspirations conveyed in oaths were understood and assimilated by the urban population at large. Not all oaths of office were revered all of the time. Furthermore, as Tittler concluded, failure to honour the terms of an oath implied both perjury and sacrilege. Cases of oath-breaking or even refusal to take an oath can therefore provide useful insights into the civic elites' success in maintaining peace and stability in cities.

\section{Oath-breaking and urban instability}

From a group perspective, an individual's reluctance to take an oath was a clear indication of the inappropriateness of that individual for membership. The Merchant Taylors' company of Bristol, for example, ordained early in the fifteenth century that all persons entering the craft should 'take a corporall othe upon the hollye evangeliste of God before the master and companye... And if anye shall refuse so to take his othe then he shall not be admitted into the saide craft nor shalbe suffred to worke therein but accepted as straunger and foreyner. ${ }^{44}$ Principled objection to swearing an oath was, however, relatively rare. Nevertheless, cases in sixteenth-century Warwick and York demonstrate how refusal to swear an oath of obedience could be used as a means of negotiating power between groups within cities. ${ }^{45}$

The negotiability of oaths was to a certain extent dependent on individual circumstances. In this respect, the Bristol civic elite authorities reserved the right to ease the rigid stipulations which it applied to the city's oaths if it was in their best interests to do so. On 14 September 1559, for example, a meeting of the common council in Bristol debated the case of Sir George Norton's membership of the Bristol community. ${ }^{46}$ Norton, it was stated, had been 'borne within this citie' and was 'a freeholder of the

42 Ricart's Kalendar, 88.

43 Ibid., 76-7.

${ }^{44}$ Fox, Merchant Taylors of Bristol, 48.

45 The Warwick assistants, for example, refused to swear the oath to the town's bailiff in 1565 , R.W. Dunning, 'The borough of Warwick: political and administrative history, 1545-1835', in The Victoria History of the County of Warwickshire: The City of Coventry and Borough of Warwick (VCH, 1969), p. 492. Similarly, the commons of York refused en masse to swear obedience to the York mayor in 1504 unless he ratified one of their petitions, E. Miller, 'Medieval York', in Tillott (ed.), City of York, 83.

46 Norton was a local gentry figure based in Abbots Leigh, near Bristol. 
same' and therefore, it was proposed, he would be 'admitted to the libertie and fredome of this citie, and be a fre burgeis'. Thus the council minutes record that Norton 'will take the corporall othe that all burgeises of the same citie use to take and receave when they be firste admitted'. If Norton 'shall think it unseemly for his estate to be founde to thinges contained in the said othe' however, then, it was decided, Norton would still 'have libertie and authoritie to buy all maner of wares and thinges necessarie for the provision of his house' in the city 'as freely as any burgeis of this citie maie doe... withowt any othe to be taken' ${ }^{47}$ Clearly in this case, Norton's patronage was considered more valuable for the city than strict adherence to the terms of the oath he was being asked to swear.

Bearing in mind both the sincerity and solemnity of oaths and the marriage of secular and sacred responsibilities which they impressed upon oath-takers, it is unsurprising that cases of oath-breaking were regarded as serious offences which carried severe punishments. In 1519 the Bristol sheriff William Dale complained to both the Bristol authorities and the Court of Star Chamber of the excessive financial burden of his office. His complaint was met with a cold reply from the mayor of Bristol, who retorted by quoting the terms of his oath back at him, reminding him that when men are made burgesses and common councillors in the city 'they ought to submytt them selfe and to accepte the same, and to be sworne upon the holy Evangelistes for to supporte and menteign the franchises, liberties, ordynaunces and landable customs and usages of the same Towne, and also to be obedient to the Maior of the said Towne and mynysters of the same'. Dale was subsequently condemned in vitriolic language for his 'malicious high and presumptuous mynd' and for conspiring 'with dyvers others ill disposed persons ... to Infrynge and breake the auncient and landable usages customs and orders of the... Towne and to the perilous example of other lyke offenders and contrary to his and their othese' ${ }^{48}$ Clearly from the Bristol civic elite's perspective, the danger that Dale's contempt for his oath might encourage similar actions from others was a threat to the maintenance of law and order in the city. More than this, however, the elite's response also highlights the extent that, in the elite's eyes, the city's oaths of office had by this time became such a crucial part of the system ensuring peace and stability that breach of oath was now considered tantamount to an attack on the city's legal and historical foundations, its ancient customs and its heritage.

Oaths could also be used as devices against elites and as thus threatening to the maintenance of good order in the local community itself when they were adopted by those wishing to subvert local authority. In early

47 Ordinances of Bristol, 1506-1598, ed. M. Stanford (BRS, 41, 1990), 28.

48 The Great White Book of Bristol, ed. E. Ralph (BRS, 32, 1979), 79-80. 
seventeenth-century Norfolk, for example, neighbours complained that Richard Sheepheard often returned home drunk and beat his wife and children. It was further claimed that he refused to pay the rent for his town house, and abused the churchwardens and other inhabitants with "'such fearful blasphemies, oaths, reproached and threatnings" that his neighbours were afraid he would set fire to their homes'. ${ }^{49}$ Similarly, when in 1479, Thomas Norton, a prominent Bristolian, accused the mayor of the city of high treason, the mayor counter-claimed that Norton had 'reteigned diverse riotous misgoverned and idell persons dwelling in Bristowe... some by gevinge of livery some by Othe and promys' ${ }^{50}$

The most severe punishment for oath-breaking in the urban sphere entailed the loss of one's political and economic freedom and hence a denial of one's civic liberties. In 1667 a Bristol cook, John Walter, lost his freedom of the city (was discommuned) for colouring strangers' goods, an offence 'contrary to the oath of a free burgesse of this citty'. The implications were very serious indeed. It was ordained that 'he shalbe taken and reputed to all intents and purposes as a foreigner, and in all respects to be dealt withal accordingly'. Furthermore, Walter's loss of burgess status had important social implications also. The city chamberlain was instructed 'forthwith to shutt downe his shop windowes', and the Bellman was instructed to 'publish the same up and downe the citty and particularly att the doore of the said John Walter'. ${ }^{51}$ Thus, just as the freeman's oath Walter had sworn sometime beforehand led him into an exclusive group of citizens within the city, by breaking this oath, Walter was ejected from this group. ${ }^{52}$

The harmonious virtues of oaths portrayed by Charles Phythian Adams in Coventry which, he claims, were indicative of the tight organization of the city's community and which, he says, helped Coventry to become 'a society bound together by oaths at each step in the citizen's lifecycle', did not necessarily find resonance in Bristol. ${ }^{53}$ Oaths of office were important devices by which power, and thus order, in late medieval and early modern cities was established, conveyed and negotiated. The evidence presented here suggests that oaths and oath-taking could be highly contentious touchstones; points at which the demarcation between the socially, politically and economically 'included' and the 'excluded'

49 S.D. Amussen, 'Gender, family and the social order, 1560-1725', in Anthony Fletcher and John Stevenson (eds.), Order and Disorder in Early Modern England (Cambridge, 1985), 211.

50 The Great Red Book of Bristol, ed. E.W.W. Veale, vol. IV (BRS, 17, 1953), 62.

51 Ordinances of Bristol, ed. Stanford, 109.

52 In this way, William Fox, a town councillor of Wells who had been discommoned in 1478, returned to the common hall some years later to renew his oath and his membership, Shaw, Creation of a Community, 194.

53 Charles Phythian-Adams, Desolation of a City, Coventry and the Urban Crisis of the Late Middle Ages (Cambridge, 1979), 180-1. 
became patently clear. ${ }^{54}$ In this sense oaths were as potentially disruptive and divisive as they were concordant. For every man portrayed by Robert Ricart who was privy to the mayor's oath-taking in Bristol hundreds outside the Guildhall were not. The promise of the Bristol mayor and sheriffs to 'disturbe no mans right' was a self-serving dictum. Ostensibly representing the civic ideal of burgess status, in reality it was designed less to uphold civic liberties or for the benefit of the collective commonweal, and more to assist the ruling elites in the maintenance of the city's good order.

54 On this theme see also Ben McRee, 'Unity or division? The social meaning of guild ceremony in urban communities', in B.A. Hanawalt and K.L. Reyerson (eds.), City and Spectacle in Medieval Europe (Minneapolis, 1994), 190-1. 